\title{
Article
}

\section{The Role of Users in Socio-Technical Transitions - Local Energy Initiative Photovoltaic}

Véronique Vasseur ${ }^{1, *}$

${ }^{1}$ International Centre for Integrated Assessment and Sustainable Development, University Maastricht / P.O. Box 616, 6200 MD Maastricht, The Netherlands

E-Mails: veronique.vasseur@maastrichtuniversity.nl

* Author to whom correspondence should be addressed; Tel.: +31-433-883-223; Fax: +31-433-884916

Received: 04 November 2013/Accepted: 04 November 2013 / Published: 05 November 2013

\begin{abstract}
Local energy initiatives (LEI) are self-supporting participatory energy generation projects in which for example solar energy is produced in the vicinity of the participants. This means that a participant is both the producer and the consumer of the solar electricity (prosumer) and that the electricity is produced in the vicinity of its users. During the last years, the emergence of these initiatives in the Netherlands has shown a substantial growth. Due to their recent emergence little is known about the factors that stimulate or hamper the appearance and development of this phenomenon. In this paper, we investigate whether a LEI based upon active users can drive the diffusion of PV in the Netherlands and in broader view whether these initiatives can foster the transition from a fossil-fuel based system to a more sustainable energy based system. The neighborhood Biesland in Maastricht is used as a case study and shows throught the use of a questionnaire that there is a demand for such a product.
\end{abstract}

Keywords: Socio-technical transitions; local energy initiatives; photovoltaic 


\section{Introduction}

While the definition of a transition may refer to any societal change, most authors in the transition literature limit themselves to technological changes. To study technological innovation, authors use a socio-technical systems perspective. Scholars recognize the relative neglect of cultural and social aspects in their theories [e.g. 1,2], while changes in technological systems also imply changes in routines and behaviour for the actors involved. This is the case with research which focuses on the 'social' aspect of socio-technical transitions within the transition literature, e.g. Shove and Spaargaren. Both researchers have studied the specific conditions for consumption in socio-technical systems like energy, water and waste systems, and formed a theoretic basis of the relations between providers and consumers. Although Shove and Spaargaren offer similar criticisms ${ }^{1}$ of transition theory, their approaches are not equal. Shove stresses the importance on how social practice ${ }^{2}$ have changed over time, how it becomes normal and what the consequences on sustainability are, by using the concepts of cleanliness, comfort and convenience. Spaargaren uses this theoretical approach by Shove and put the social practices into a conceptual model, which has a strong emphasis on sustainability of existing lifestyles and on the ecological modernization of the society. Thus, in these approaches the involved people are used as objects to change and not as an active actor in the transition process which go beyond the common notion of routines and behaviour of people. In this research we are interesting in the active actor, more in particular, people who are engaged in the transition process as 'subject of change' instead of 'object of change'. Local energy initiatives (LEIs) are built upon this kind of actors/citizens. Behind these initiatives, the general idea is that it is a self-supporting participatory energy generation project in which for example solar energy is produced in the vicinity of the participants. This means that a participant is both the producer and the consumer of the solar electricity (prosumer) and that the electricity is produced in the vicinity of its users ${ }^{3}$. During the last years, the emergence of these initiatives in The Netherlands has shown a substantial growth. Due to their recent emergence little is known about the factors that stimulate or hamper the appearance and development of this phenomenon. Therefore the purpose of this paper is to investigate how local energy initiatives regarding solar energy, also called LEI-PV, can drive the diffusion of PV in The Netherlands and in broader view whether these initiatives can foster the transition from a fossil-fuel based system to a more sustainable energy based system. To know what such an initiative all is about and why it can stimulate or hamper the diffusion of PV, it is not enough to explain how it actually can be that driver. It must also be known how it can be created and who can contribute in which way in order to facilitate this creation. The neighbourhood Biesland in Maastricht will be used as a case study.

\footnotetext{
${ }^{1}$ Both authors argue that the social practices are discussed in socio-technical analysis, but that 'socio' in practice is interpreted very narrowly. The emphasis is on systems, markets, institutions, infrastructure, and there is little room for how people really behave, what their lifestyle are in terms of food, move or live, how and why they make choices.

${ }^{2}$ The concept of social practice refers to "a routinized type of behaviour which consists of several elements interconnected to one other: forms of bodily activities, forms of mental activities, 'things' and their use, a background knowledge in the form of understanding, know-how, states of emotion and motivational knowledge" (Reckwitz, 2002, p. 249).

${ }^{3}$ This phenomenon is also called Energy Service Companies (ESCOs) or Local Renewable Utilities (LRU). Currently there is not a common term used for this phenomenon but we prefer initiatives above companies or utilities because it also covers projects with a certain time range and/or goal (e.g. $20 \%$ renewables before 2020)
} 


\section{Theoretical background}

Local energy initiatives (LEIs) are part of a trend away from the present conventional top-down and centralized structures of energy provision towards innovative bottom-up and decentralized managed methods of energy provision. Agentschap NL [3] described it as a business like operating independent entity that has the objective to execute local generation and/or delivery of sustainable energy in the form of heat and electricity and to realize energy savings. This description is in line with the definition of the Ministry of Economic Affairs [4], they defined a LEI as 'an entity that generates and/or uses4 local energy, whereby energy can consist of sustainable heat and/or sustainable electricity'. The concept of local energy is then again defined, according to the vision of Minsitry of Economic Affairs, as 'sustainable energy generation whereby the produced energy is used in proximity of the place where the energy is generated' [4 p. 2-3]. Within this context, it implies that the generation and/or delivery of energy and/or energy saving takes place within a geographically delineated area. Often it is a partnership of citizens or local parties and a municipality or housing association. Many of the current initiatives are driven by the needs for social benefits, such as contributing to more sustainable energy or controlling energy costs for residents [3 p.4].

The literature on LEIs can be distinguished in three strands of research. One strand focused on the role of public perceptions and community ownership in local sustainable energy initiatives. Walker et al [5] investigate the role of community and trust on the success of local sustainable energy initiatives. They conclude that local sustainable energy initiatives are most successful when there is a high level of trust within the community. St Denis \& Parker [6] study the role of community from a different perspective. Their study on community energy planning in Canada starts from the assumption that local sustainable energy management is desirable as it contributes to a reduction in $\mathrm{CO} 2$ emissions and to self-sufficiency. However, their study demonstrates that most communities prefer energy efficiency improvements to the local production of sustainable energy. Only a small number of remote communities were willing to implement local energy production and management within their energy plans. Therefore, they concluded that these remote communities are most likely to lead the transition towards a more sustainable society.

The second strand focused on the future prospects of local energy in order to conclude with policy recommendations. Within this strand, Allen et al [7] provide a general analysis of the prospects of and barriers to local energy production in the UK. Szatow et al. [8] study the barriers to distributed generation in Australia and conclude that the main barrier is lack of commercial viability due to policy and regulatory uncertainty. Passey et al. [9] discuss the technical implications of embedding distributed energy production to the central grid, while Sauter \& Watson [10] discuss the implication of social acceptance. The economic prospects and economic barriers of local sustainable energy are discussed by Watson [11]. Consequently, Watson et al. [12] discuss a variety of policy interventions with the objective to create a level playing field for micro-generation technologies. From the perspective of transition pathways, Verbong and Geels [13] and Bergman \& Eyre [14] discuss the policy

\footnotetext{
${ }^{4}$ For the purpose of this research, the term delivery that was present in the definition of Agentschap NL is replaced by the term use. The reason for this is that under current Dutch legislation it is impossible for a LEl to deliver its own energy to the public (low-voltage) grid without involvement of an energy supply company (Elektriciteitswet 1998, Art. 95a, lid2, sub a and c). Therefore, the term use captures more adequately the main characteristic of a LSEI; namely the fact that the producers are at the same time the users of local energy.
} 
interventions required to achieve a sustainability transition in which local sustainable energy plays an important role.

The third strand studied a variety of factors that account for differences between countries regarding the role of local sustainable energy. Toke et al [15] - who investigated wind power deployments - state that planning systems, systems of financial support, landscape protection organisations and local ownership patterns are important determinants in explaining the level of wind power deployments in a specific country. Lopes Ferreira et al [16] investigate the role of diversity within the distribution market on the level of distributed generation. They state that a high level of unbundling within the power distribution sector contributes to a higher level of distributed generation. Davies and DiazRainey [17] use cross-national data to study how policy interventions in affect the patterns of diffusion.

From this overview it becomes clear that there is little scientific research on the identification and assessment of possible explanatory factors, i.e. stimulate or hamper, that might determine the emergence and development of LEIs. The innovation diffusion literature provides building blocks to construct a theoretical foundation. However, these theories remain too abstract to study the emergence and development of LEIs. Decentralisation of energy provision through LEIs appears on multiple levels, ranging from individual households to regional cooperative arranged organisations, and can involve a diverse composition of actors with different motives, responsibilities and forms of ownership. Moreover, renewable energy within an initiatives/organization can be generated through multiple technologies, e.g. solar energy or wind energy. Because of these reasons, there exist many different ways in which these technical and social aspects can interact with each other. From the complete spectrum of possible interactions, Walker and Cass [18] outlined five modes in which renewable energy has been implemented in the UK and how these involve different configurations of technology and social organisation. They specifically use the term mode in preference to the terms regime and niche that are commonly used in the literature on socio-technical systems since mode allows for greater simultaneous heterogeneity and avoids some of the problematic assumptions of the deliberate nested hierarchical transition management framework [18]. The five modes are public utility, private supplier, community, household and business. In line with the above mentioned description of LEIs, the community and household mode discussed by Walker and Cass (2007) are interesting in this research as the focal point is on local arrangements founded by civilians or inhabitants, which enables community members to own and utilize renewable energy technologies.

Based on the description of a LEI, a plethora of different initiatives can be distinguished that vary in locality on both process and outcome dimensions. More specifically, these initiatives can roughly be split up into two main categories namely the LEIs that form technology specific local sustainable initiatives and local sustainable energy companies [19]. Although this is not a clear cut categorisation, since technological specific local initiatives can also be local sustainable energy companies and local sustainable energy companies can also finance/participate in technological specific LEIs, it is nevertheless useful to perceive them as a distinct category because they each have their own internal developmental dynamic [19].

With regards to the technology specific local sustainable initiatives, roughly four different sources of energy can be distinguished, namely wind energy, solar energy, biomass and geothermal energy. These different sources can be applied through a variety of technologies to generate energy in the form of electricity, gas or heat. Especially for the case of biomass, an overlap can be found. For example, a 
LEI using biomass can produce biogas which can deliver input to a combined heat and power (CHP) that will generate both energy in the form of electricity and heat. The other category, the local sustainable energy companies, often makes use of different sources of energy. They can also be involved in the trading of energy, in other words, they purchase energy from (other) sustainable energy producers and they sell and deliver this energy to their own customers. However, these initiatives should not be seen as local front offices of national energy suppliers, because lots of these companies were founded as a direct response to dissatisfaction with the market power of those large suppliers (Schwencke, 2012, p. 22). Texel Energie and Zutphense Energietransitie are two examples of this latter category.

\section{Local Energy Initiative - PV}

The central idea underlying local energy is that members of a LEI both generate and use their own local energy [20]. Therefor we would like to further narrow down the unit of analysis to LEIs using solar energy (LEI-PV) that both produce and consume (presume) local energy in the form of electricity. The restriction to PV can be motivated by the argument that LEI-PV are most numerous and are growing at a particularly quick rate [21]. Consequently, LEIs that have already achieved this ambition (both prosume and consume local energy in the form of electricity) can be considered as frontrunners within the field. These frontrunners are especially relevant for the identification of drivers and barriers as they might indicate future trends within the field of LEI as well. The political demand provide room for these initiatives to diffuse and develop themselves further is particularly strong. This political demand directed at local initiatives using PV is amongst others visible in the motion of Dutch politician van der Werf on December 5, 2011 [22] and the letter from e-decentraal directed at the political leaders responsible for the formation of the government in October 2012 [23]. This in turn might have led these political leaders to specifically mention solar initiatives - next to generally referring to local energy generation - when proposing a diminished fiscal tariff for local energy as one of the key measures that the government intends to implement in its government term [24 p.9].

Within this PV technology, three different types of initiatives can be distinguished. First, we have district initiatives. In this type of initiatives, production and/or use of sustainable electricity typically take place within a city district, neighbourhood or other socially and geographically delineated area. Social cohesion plays an important role in these initiatives, consequently, cooperation on energy sometimes spills over to other areas such as communal gardens and car sharing. Initiatives that fall within this category can be initiated by homeowners associations [19]. A homeowners association is an organisation made up of neighbours concerned with managing the common areas of a condominium complex. An example of a district initiative is 'Zon op VvE', started by the municipality of Amsterdam in cooperation with a few homeowners associations. Within this initiative, electricity is generated from PV panels that are placed on the roof of an apartment complex. The electricity that is generated from this collective roof is in turn divided amongst the apartment owners, without individually connecting those apartment owners to the PV production installation on their roof. Instead, PV panels are directly linked to the collective electricity meter of the apartment complex. When the PV panels are producing more electricity than is used for the collective services of the apartment 
building, the excess of electricity is placed back on the grid. In turn, the turnover of the produced electricity is administratively divided over the individual apartment owners. Each apartment owner receives a discount on their electricity bill that corresponds to their investment in the PV panels (Municipality of Amsterdam, 2012).

The second category are initiatives that focus on the collective procurement of the technology. There is a mushrooming of initiatives that collectively procure PV panels. Almost all energy suppliers offer PV panels packages with attractive discounts. Energy suppliers see these packages as an opportunity to both attract and retain customers. Usually, there is first a subscription round and when there are enough subscriptions, the initiatives orders the panels. Therefor the price is not fixed before the subscription [19]. An example of such an initiative is 'Wij Willen Zon', set up by the Dutch lobby organisation for sustainability and innovation 'Urgenda' and the internet platform for sustainability 'de Betere Wereld.' This initiative collectively purchased Chinese PV panels and sold them to buyers in The Netherlands [25].

The third category consists of initiatives with a separation between ownership of technology and location of production. More in detail, it consists of initiatives whereby PV panels are owned by the participants of the initiative and are being placed elsewhere e.g. roofs of farmers, government buildings or company buildings. In this type of initiatives, the ownership of the panels and the ownership of the location where the solar energy is generated are strictly separated [19]. It is difficult to distinguish these initiatives from local sustainable energy companies, especially when they also formulate the objective to also deliver sustainable energy to their members.

The business model of this type of initiatives is roughly comparable to that of wind power initiatives; members finance the PV panels through loans and become co-owner of the production installation. The ambition of many initiatives is that these members can also use their own power without paying energy tax. Similarly to the situation of wind power initiatives, the current Dutch legislation does not allow this form of self-supply. In this situation, the practice of 'salderen' plays a role. 'Salderen' can be described as a current practice in The Netherlands whereby the amount of electricity that is produced behind a retail connection is netted with the amount of electricity that is consumed. As a result no energy tax and VAT (value added tax) is levied on the amount of energy that is produced behind this retail connection, only on the electricity that is fed into the grid [26]. 'Salderen' is often not possible or at least not very straightforward by a separate ownership of technology and location of production. In many of these initiatives, Greenchoice actively collaborates in the development of rent, lease and procurement constructions and takes a strong position with regards to the practice of 'salderen'. Green Choice is developing itself as an administrator and intermediary similar to the case of a wind power station [19].

There are many projects that attempt to find creative solutions in order to reap the benefits of 'salderen'. An example of such an initiative is ENERGIE van boerENbuur, whereby farmers and neighbours invested some of their savings to collectively purchase a PV installation. This PV installation is then placed on the roof of a farmer. The electricity that is produced is being divided over the neighbours as if the installation is situated on their own roofs, thereby applying the practice of 'salderen'. However, as the tax authorities receive a lower amount of energy tax from the neighbours participating in this project, there is a risk that the tax authorities will construct a claim against the initiative for not paying taxes [27]. 
Between these three types of initiatives, there is a considerable overlap between the technology specific local sustainable initiatives and local sustainable energy companies.

\subsection{The structure of LEI-PV}

In the innovation diffusion theory a technological innovation is often described in term of three structural components, namely actors, networks and institutions [28 p.81]. The actors include firms within the whole value chain [29], as well as universities, industry organisations, intermediary organisations, NGOs and government bodies [28]. The networks can be both 'learning networks', which can link suppliers with users, related firms, competitors or researchers, and/or 'political' networks or advocacy coalitions (ibid.). The third component, institutions, is at the heart of the process whereby new technologies gain ground (ibid.).

A LEI-PV is not a technological innovation because it is not a new technology, although, it can be seen as an incremental innovation for the PV technology that can made the applicability cheaper. However, this does not make the LEI-PV an innovation, the fact that LEI-PV applies PV in a new product makes it an innovation. The new product is electricity from your own PV panels that, in most cases, are installed and maintained for you against a competitive price, no matter how long you choose to use these panels. In this way, the customer/participant is provided with the means to produce and use their own local energy and to do so according to his or her own specifications. When the PV panels are producing more electricity than is used, the excess of electricity is placed back on the grid. This is another product than is offered by traditional energy companies like Essent or Eneco, they sold electricity (conventional energy or energy from renewable energy sources) rather than the means to produce and use it. Thus, a LEI-PV can be seen as an innovation which makes the structural component also feasible to describe these initiatives in terms of actors, networks and institutions.

\section{$\underline{\text { Actors }}$}

The actor constellation within a LEI is slightly different from other technological innovations as the traditional boundaries between suppliers (producers) and users (consumers) are blurred in a LEI. The reason for this is that the members of a LEI are simultaneously involved in the production and consumption of energy. The term prosumer is often used to describe this phenomenon, it is used to describe consumers who were predicted to each become active to help personally improve or design the goods of the market place, transforming it and their roles as consumers [30]. The most important actors within a LEI are the initiators, but there are also the supply side firms such as the energy companies (e.g. Nuon, Trianel, Green Choice, Eneco) and the suppliers of the PV panels from both The Netherlands and abroad (Germany and China).

There is a variety of bridging organisations active in this field such as Hier Opgewekt, e-Decentraal and ODE. Banks are also important actors as cooperation often requires external capital to start up. Government organisations such as the Ministry of Economic Affairs, Agentschap NL, regional governments and municipalities are also involved in these initiatives. The demand side is composed of the members of the LEI. 
$\underline{\text { Networks }}$

The learning network and policy network are quite difficult to distinguish. Surrounding the national bridging organisations and the regional platforms, policy and learning networks develop simultaneously. These interchangeable networks are important for LEIs because they link the different mentioned actors, but also influence the expectations of the future, share a set of beliefs and seek to influence the political agenda. These are important processes because the initiatives need to gain ground and engage in the wider political debate in order to be successfully diffused and implemented. Policy networks or advocacy coalitions that lobby to the government were since the end of 2011 formalised through the setting up of the organisation e-Decentraal.

\section{$\underline{\text { Institutions }}$}

The institutions have played an important role during the last years. The main institutions that are of importance for the future success of LEI-PV in The Netherlands are policy goals and programs and can roughly divided into six different elements. (1) overarching target on the share of sustainable energy within The Netherlands; (2) subsidy programme - SDE+; (3) regulatory framework (set within the Elektriciteitswet 1998) [26]; (4) Green Deals that the government can close with civil society so that civil society can set up project that contribute to more sustainable energy [31]; (5) national innovation policy - R\&D budgets for sustainable energy are being awarded [32].

\section{Biesland Solar}

Although many initiatives consider the diffusion of renewables, few studies among them are dealing with solar energy. Some of the already discussed initiatives (see part 3) are contextually related and showed some interesting issues in this area. However, it is not our purpose to be exhaustive, but rather to broaden insight in the applicability of an initiative, how it can be created and who can contribute. Therefore, we decided to explain one initiative in more detail, namely Biesland Solar.

The Biesland Solar is a typical bottom-up project where the start initiative came from the local citizens. The idea was to involve the expertise that existed within the own community. This meant that no funds where spent on lawyers, process managers and consultants. The formation process was deliberately built on personal expertise. The aim of Biesland Solar is to use renewable electricity from the sun generated within the neighbourhood entirely locally by linking it to energy demand from homes and businesses which has been made manageable. But also to investigate the social aspects of the process of moving toward sustainability: how do you get the public to the point that they want to switch to renewable energy? On this communication issue the board of Biesland Solar work together with people who live in the neighbourhood.

The starting point of Biesland Solar was to give the opportunity to all the inhabitants of the neighbourhood to offer PV panels packages with attractive discounts though collectively purchase. The installation and maintenance is provided and regulated thought the cooperation. Moreover, they provide information to the inhabitants and thus encourage them to use renewable energy, in particular solar energy, and to match their energy demand to the supply. The board placed an advertorial in a local newspaper in which they supported this initiative and called on other citizens to join this 
initiative. Also an information meeting was organized in the neighbourhood to inform the inhabitants. The need for more information about the ins and outs of solar energy was indicated by Vasseur and Kemp [33], not only information concerning costs and quality aspects seem to be important, also information on social and environmental matters. Their findings also suggest that it is important to create attention by the group non-adopters. In order to investigate whether information meetings play a relevant role in the adoption process of people, we executed a survey containing both closed and open questions among the inhabitants of Biesland who attended an information meeting.

The questionnaire first addressed a number of general solar energy questions to test differences in tacit knowledge and preferences. Subsequently the questionnaire continued with questions specifically aiming at investigating the usefulness of the meeting. All questions were kept as basic as possible to ensure that the research population would understand the questions. The final part of the questionnaire consists of general demographic questions.

As also mentioned before, the purpose of this research is to broaden insights in the applicability of a LEI. Therefor we use descriptive statistics to describe the main features of the collection of data obtained via the questionnaire in quantitative terms.

\subsection{Results}

The questionnaire is completed by 18 people, which corresponds to 18 households in the neighbourhood Biesland who have currently not adopting a PV system. All the respondents are homeowners and are satisfied with their living situation5. 17 out of the 18 respondents indicated that they have considered the purchase of a system. It shows the willingness to invest in the technology, but the real adoption has not taken place yet. In this research we call the group of people who considered the purchase the potential users of PV.

The willingness is also confirmed by a recent study of the University of Groningen. Stokman and Wolfs [34] investigated the willingness to take part in initiatives for local production of renewable energy in three municipalities in the north of The Netherlands (Veendam, Stadkanaal and Oldambt). Local residents were asked whether they would participate in cooperative initiatives. $35 \%$ of the respondents would immediately participate and another $27 \%$ would participate if a good number of other people had joined the initiative (social cohesion). $65 \%$ of the respondents would definitely put a PV system on their roof [34].

In this research we go one step further and also examined the considerations why the real adoption has not yet occurred. In Table 1 the importance of the aspects are ranked from important to unimportant. The results show us that there is a vast majority who first will obtain more knowledge regarding the possibilities and who found the high investment cost of PV the most important aspects, followed at a large distance with the other aspects.

A subsequent analysis tested in which situation people would adopt a system. A payback period of maximum 5 years is ranked at the first position, followed by attractive subsidies and lower investment costs.

\footnotetext{
${ }^{5} \mathrm{~A}$ likert-scale, ranging from disagree ( 1 point) to agree (5 points), pointed out that 16 responds gave 5 points and 2 respondents gave 4 points for the satisfaction of their living situation.
} 
Table 1. What are the reasons for not adopting a PV system and under which circumstances would you adopt a PV system, ranked from important to unimportant

\begin{tabular}{|l|c|}
\hline Reasons for not adopting a system & $\begin{array}{c}\text { Number of } \\
\text { respondents }\end{array}$ \\
\hline $\begin{array}{l}\text { Lack of information / will gather more } \\
\text { information }\end{array}$ & 10 \\
\hline Investment is too high & 9 \\
\hline Energy yield is too low & 3 \\
\hline Fear of gaining promised efficiency & 2 \\
\hline Visual representation & 2 \\
\hline Fear of subsidy adjustments & 2 \\
\hline Too innovative & 1 \\
\hline I am too old & 1 \\
\hline No reason at all & 1 \\
\hline
\end{tabular}

\begin{tabular}{|l|c|}
\hline $\begin{array}{l}\text { Under which circumstances would you adopt } \\
\text { a system }\end{array}$ & $\begin{array}{c}\text { Number of } \\
\text { respondents }\end{array}$ \\
\hline If the payback is 5 years max & 7 \\
\hline If there is an attractive subsidy program & 6 \\
\hline If the investment drops significantly, $+/-25 \%$ & 5 \\
\hline If the payback is 7.5 years max & 4 \\
\hline If the quality of the system improve & 3 \\
\hline If the investment drops significantly, $+/-50 \%$ & 2 \\
\hline If the payback is 2.5 years max & 1 \\
\hline If the system is nicely integrated & 1 \\
\hline If the yield is good & 1 \\
\hline
\end{tabular}

We queried respondents about their generic knowledge of PV. Of the 16 respondents that answered the question, a total of 11 reported to be familiar with the costs and 8 reported that the investment is affordable. Interested, 7 out of these 8 respondents reported that they are considering the purchase of PV panels at the moment and the remaining respondent has not an opinion.

It is remarkable that $78 \%$ of the respondents reported that they were aware of a subsidy program while for all the subsidy procedure is not seen as a main barrier. $78 \%$ of the respondents are also aware of the operation of the system, $83 \%$ of the lifetime and $78 \%$ of the pay-back period. These findings suggest that public information about the possibilities and the procedures is not necessary. However, the results indicated that there is a need for information concerning the possibilities of the system, 13 out of 17 respondents. The majority of the respondents consulted three different types of sources during their search for information regarding PV systems. There were up to five different types of sources consulted, however only one respondent indicated the use of so many different sources. In Figure 1, the different types of sources are represented. We see that friends, family and acquaintances are most consulted for information regarding solar energy by the respondents. This is in line with earlier findings from Stern [35], in his research he also indicated the strong influence of information from non-expert friends on household energy decisions. We further investigate the social aspects of moving towards living more sustainable. $47 \%$ of the respondents indicated that people within their social environmental already have a system and $29.5 \%$ of the respondents have neighbours which adopted a system. However, discussion with other adopters to convince adoption is marginal, only one respondent feels pressure from the social environment while $70.5 \%$ already spoke with their social environment.

Articles in newspapers, websites from installation companies and information meetings are other frequently used types of information sources. Especially the installers can play an important role during the decision process. Most of the interested people will contact several installers in their search for more information and the best buy. In earlier research, consumers already indicated that installers could play a role in encouraging further behaviour change [36]. This is important information for the installers, besides giving information regarding PV systems, they can also give information regarding other environmental investments and environmental concerns. Remarkable, architects are not mentioned as source while they can play an important role in the further diffusion of PV systems. 


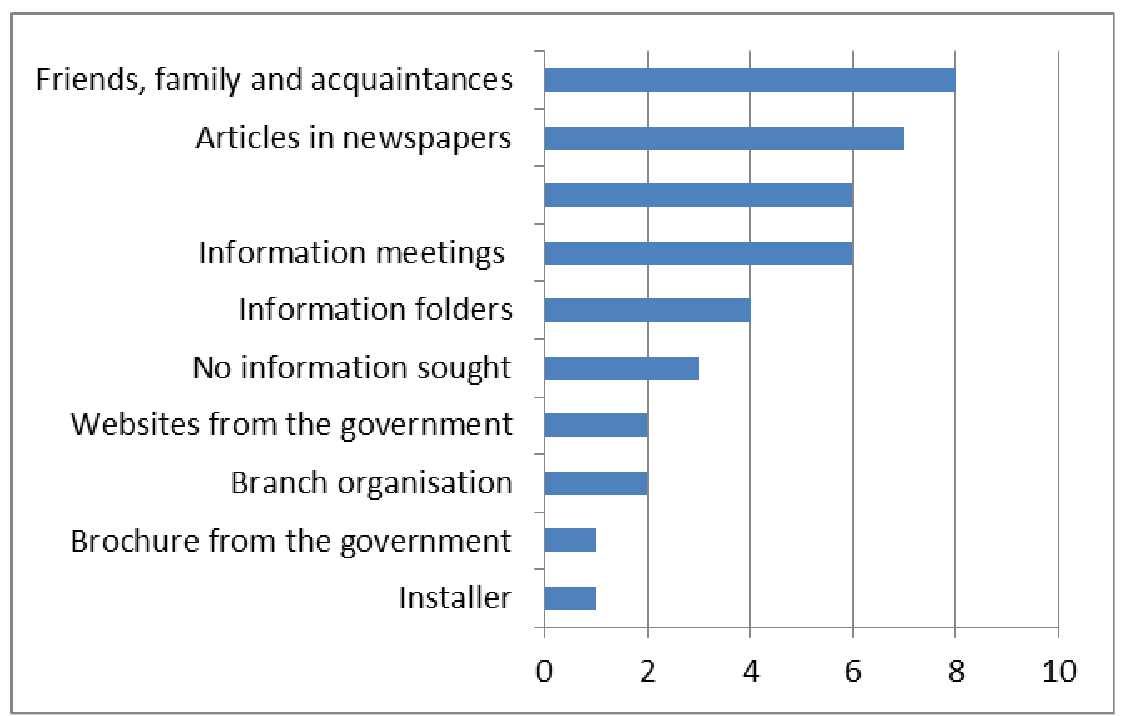

Figure 1. Different types of information sources consulted by the respondents

We also investigate what important product attributes/characteristics for a PV system are and how these attributes are ranked. We asked the respondents to rank, important or not important, several PV related attributes which are important in the decision process to adopt or not adopt a system. The different attributed were: (1) efficiency - amount of energy (2) integration (3) lifetime of the system (4) price and (5) visual representation. In Table 2 the different attributes are given with the corresponding percentages. These findings indicate that cost and efficiency of a solar system are major issues perceived by the respondents. Since the questionnaire have not asked people about the relative importance of the several aspects of this cost (purchase, operating costs, maintenance costs, and insurance rates) it is impossible to determine which are perceived as most important. The PV technology keeps on developing and its main component, the PV cells, are expected to become more efficient in converting solar energy into electricity [37]. The performance ratio, the fraction of the output of the solar cells that is fed to the grid, is also expected to grow in the future [38]. The overall system efficiency is the multiplication of the cells efficiency with the performance ratio (PR).

A vast majority of the respondents found concern for visual aspect of a set of panels (see integration and visual representation) less important than the other mentioned attributes. This is against our expectations because the visibility of the technology can function as a status symbol or serve as a symbol to communicate a certain identity or value orientation.

Table 2. Attributes of a PV system (percentages)

\begin{tabular}{|l|c|c|c|}
\hline Attributes & Important & Less important & Dutch population \\
\hline Efficiency-amount of energy & 100 & 0 & 20.9 \\
\hline Integration & 55.6 & 44.4 & 4.9 \\
\hline Lifetime of the system & 93.3 & 6.7 & 5.4 \\
\hline Price & 100 & 0 & 66.0 \\
\hline Visual representation & 28.5 & 71.5 & 2.8 \\
\hline
\end{tabular}

We assume that the reason for people focusing mainly on the costs is that not a lot of information exists on the other matters. Important to mention here is that we in this analysis only took the attributes of a PV system into account, we have not asked people about the relative importance of several other aspects for example related to the advantages of having a system e.g. environmental benefits and independency from electricity suppliers. 
A LEI can provide different services such as facilitating the collective procurement of PV system. The importance of different services or aspects of the LEI are investigated by asking the respondents which aspects are important for them (multiple answers possible), the results are given in Figure 2.

A lower electricity bill is ranked at the first position, followed by the collective procurement and the independency of large monopolistic energy companies.

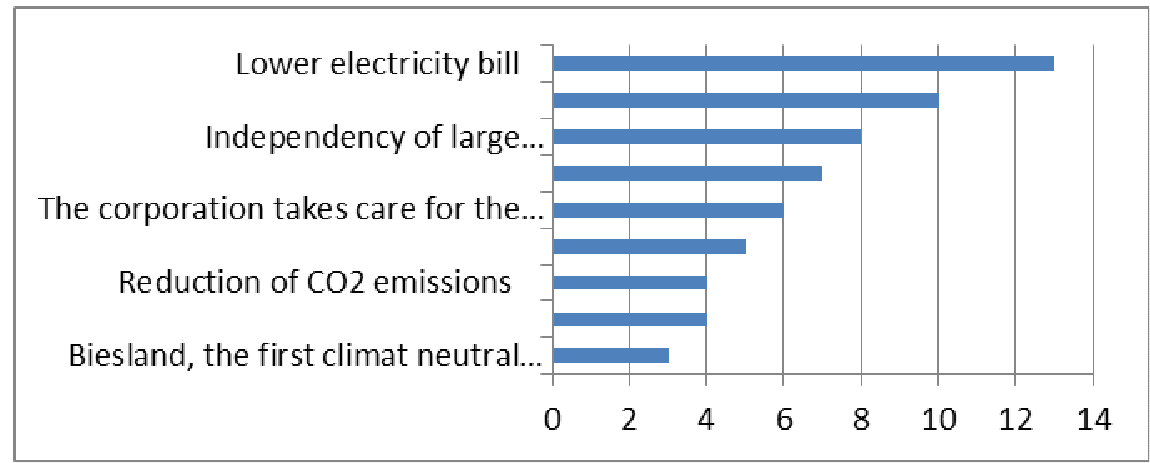

Figure 2. Important services/aspects within LEI

Finally, we queried the respondents about their impression of the Biesland Solar initiative and the information meeting. We asked the respondents to indicate their impression using 5-points Likert-scale ranging from 1 (negative) to 5 (positive). The respondents were positive about both, the initiative was rated a 3.9 and the information meeting a 3.6. The majority of the respondents (10 out of 17) is more positive over the installation and the use of PV than before the information meeting, the remaining part indicated that the meeting has confirmed their vision regarding solar energy. Nobody indicated to become negative after the meeting. The willingness to adopt a PV system is increased by $72 \%$ of the respondents (13 out of 18). These results confirm the usefulness of such meetings, it indicates that information can be seen as an important way to take the lead and that these information meetings can play a relevant role in the adoption process of people. However, at the moment there is no evidence that such information alone would motivate anyone to buy a system.

\section{Conclusion and discussion}

In this paper we described the LEIs to explain the role of users in socio-technical transitions. Users in social-technical transitions are often used as object to change in the literature, however, we decided to involve them as subject of change. LEIs are built upon this kind of users. In this paper, we investigated whether a LEI based upon active users can drive the diffusion of PV in The Netherlands and in broader view whether these initiatives can foster the transition from a fossil-fuel based system to a more sustainable energy based system. In the previous sections it was showed that a LEI can stimulate the diffusion of PV systems through opening up the market for home PV systems. The reactions of local residents in the neighbourhood Biesland to the concept of the LEI-PV, as experienced in the questionnaire, suggest that there is a demand for such a product. This is also confirmed by a study of the University of Groningen [34].

Based on the literature and the performed questionnaire, we formulated three trends within the LEIs which make it clear why they can drive the diffusion of PV in The Netherlands. First, LEIs can facilitate the collective procurement of PV in order to gain economies of scale. The systems will become competitive and therefore it should be possible to exist without government subsidies in the 
near future. In this way a substantial and constant demand for PV systems will be created which probably stimulate the diffusion of PV in The Netherlands. Second, LEIs make PV systems legitimate by spreading a positive image of PV systems through referencing, however, there is no empirical evidence to confirm that discussion with other adopters convince adoption. Third, LEIs educate and facilitate people with the ins and outs regarding solar energy to reduce perceived complexities. Hiring experts could have more and longer effect on the diffusion of PV than spending the money directly on subsidies.

This paper is meant as a first step to investigate whether LEIs based upon active users can drive the diffusion of PV in The Netherlands. How the decision-making process over time looks like becomes not clear from this research. It may seems obvious that early adopters generally make independent decisions and are guided by their needs whereas late adopters are more influenced by their social network, however, this phenomenon should be further investigated. In this research the emphasis should be on how economic considerations and technological aspects are taken into account in combination with the timescale of awareness and actual adoption of PV. Moreover, due to the rapid development of LEIs and the various forms in which LEI appear, further research on other established initiatives should contribute our understanding whether these initiatives can foster the transition from a fossil-fuel based system to a more sustainable energy based system. On conceptual level, further research remains necessary on how to further integrate these active users in socio-technical transitions.

\section{Acknowledgments}

The authors would like to thank Prof. René Kemp and Dr. Marc Dijk who had a significant role in this research project. Also the authors would like to express their gratitude towards every survey respondent. We also would like to thank the INTERREG and the ORGANEXT project for their financial support.

\section{Conflict of Interest}

The authors declare no conflict of interest.

\section{References and Notes}

1. Genus, A. and A.M. Coles, Rethinking the multi-level perspective of technological transitions. Research Policy, 2008. 37(9): p. 1436-1445.

2. Geels, F.W., Technological Transition and System Innovations. A Co-Evolutionary and SocioTechnical Analysis, . 2005, Cheltenham UK and Northampton MA: Edward Elgar Publishing.

3. Agentschap NL, Wetten \& regels voor Lokale duurzame energiebedrijven. 2011, Agentschap NL: Utrecht.

4. $\quad$ Min EZ, Visie Lokale Energie (internal document). 2013, Ministerie van Economische Zaken.

5. Walker, G., et al., Trust and Community: Exploring the meanings, contexts and dynamics of community renewable energy. . Energy Policy, 2010. 38(6): p. 2655-2663.

6. St Denis, G. and P. Parker, Community energy planning in Canada: The role of renewable energy. . Renewable and Sustainable Energy Reviews, 2009. 13(9): p. 2088-2095.

7. Allen, S.R., G.P. Hammond, and M.C. McManus, Prospects for and barriers to domestic micro-generation: A United Kingdom perspective. Applied Energy, 2008. 85(6): p. 528-544. 
8. Szatow, A., et al., Distributed Energy and its stakeholders: Making sense of the distributed energy landscape in Australia. . 2009, CSIRO: National Research Flagships: Australia.

9. Passey, R., et al., The potential impacts of grid-connected distributed generation and how to address them: A review of technical and non-technical factors. Energy Policy, 2011. 39(10): p. 6280-6290.

10. Sauter, R. and J. Watson, Strategies for the deployment of micro-generation: Implications for social acceptance. Energy Policy, 2007. 35(5): p. 2770-2779.

11. Watson, J., Co-provision in sustainable energy systems: the case of micro-generation. . Energy Policy, 2004. 32(17): p. 1981-1990.

12. Watson, J., et al., Domestic micro-generation: Economic, regulatory and policy issues. . Energy Policy, 2008. 36(8): p. 3095-3106.

13. Verbong, G.P.J. and F.W. Geels, Exploring sustainability transitions in the electricity sector with socio-technical pathways. Technological Forecasting \& Social Change, 2010. 77(8): p. 1214-1221.

14. Bergman, N. and N. Eyre, What role for microgeneration in a shift to a low carbon domestic energy sector in the UK? . Energy Efficiency, 2011. 4(3): p. 335-353.

15. Toke, D., S. Breukers, and M. Volsink, Wind power deployment outcomes: How can we account for the differences? Renewable and Sustainable Energy Reviews, 2008. 12(4): p. 11291147.

16. Lopes Ferreira, H., et al., Distributed generation and distribution market diversity in Europe. Energy Policy, 2011. 39(9): p. 5561-5571.

17. Davies, S.W. and I. Diaz-Rainey, The patterns of induced diffusion: Evidence from the international diffusion of wind energy. . Technological Forecasting and Social Change, 2011. 78(7): p. 1227-1241.

18. Walker, G. and N. Cass, Carbon reduction, 'the public' and renewable energy: engaging with socio-technical configurations. Area, 2007. 39(4): p. 458 - 469.

19. Schwencke, A.M., Energieke BottomUp in Lage Landen - De Energietransitie van Onderaf Over Vrolijke energieke burgers Zon- en windcoöperaties Nieuwe nuts 2012, AS I-Search: Leiden.

20. $\quad$ Min EZ, Regeling Vaststelling Definitieve Correcties Duurzame Energieproductie 2011. 2012, Ministry of Economic Affairs: Den Haag

21. Polder-PV. Eindelijk nieuwe cijfers CBS grafieken. 2012 [cited 2012 November 23]; Available from: http://www.polderpv.nl/nieuws PV94.htm.

22. Overheid.nl. 33000 XIII: Vaststelling van de begrotingsstaten van het Ministerie van Economische Zaken, Landbouw en Innovatie (XIII) voor het jaar 2012. Nr. 69 Motie van de Leden van der Werf en Wiegman-van-Meppelen Scheppink. 2011 [cited 2013 January 8]; Available from: https://zoek.officielebekendmakingen.nl/kst-33000-XIII-69.html.

23. e-Decentraal. Brief e-decentraal aan Tweede Kamer - Voorstel aanpassing salderingsmogelijkheden. 2012 [cited 2012 October 10]; Available from: http://www.hieropgewekt.nl/sites/default/files/documents/20121010-Brief-aan-2de-kamerdecentraal-duurzaam-brede\%20alliantie.pdf.

24. $\quad$ Regeerakkoord, Bruggen slaan: Regeerakkoord VVD - PvdA, 29 oktober 2012. 2012.

25. Wij willen zon. Betaalbare zonnepanelen op uw dak. 2013 [cited 2013 March 4]; Available from: http://www.wijwillenzon.nl/.

26. AgentschapNL, Zonnestroom en de Nederlandse wetgeving. 2012, Agentschap NL - NL Energie en Klimaat: Utrecht.

27. BOER zoekt BUUR. ENERGIE van BoerENbuur... = Samen ENERGIE produceren EN consumeren! . 2012 [cited 2013 January 8]; Available from: http://www.boerzoektbuur.nl/energie-van-boerenbuur/.

28. Bergek, A., M. Hekkert, and S. Jacobsson, Functions in innovation systems: a framework for analysing energy system dynamics and identifying system building activities by entrepreneurs and policy makers, in Innovations in Low-Carbon Economy, T.K. Foxon, J.; Oughton, C, Editor. 2008, Edward Elgar. p. 79-111. 
29. Porter, M.E., Competitive Advantage 1985, New York: The Free Press.

30. Toffler, A., The Third Wave 1980, USA: Bantam Books

31. Rijksoverheid. Green Deal. 2012 [cited 2013 March 6]; Available from: http://www.rijksoverheid.nl/onderwerpen/duurzame-economie/green-deal.

32. Topsector Energie. Energie. 2012 [cited 2013 March 6]; Available from: http://www.topsectoren.nl/energie/.

33. Vasseur, V. and R. Kemp, The adoption of PV in the Netherlands: A statistical analysis of adoption factors Renewable \& Sustainable Energy Reviews, Under Review

34. Stokman, F.N. and J. Wolf, Bereid om mee te doen met initiatieven voor lokale productie van duurzame energie. 2011, University of Groningen: Groningen, the Netherlands.

35. Stern, P.C., What psychology knows about energy conservation. American Psychological Association, 1992. 47(10): p. 1224 - 1232

36. Keirstead, J., Behavioural responses to photovoltaic systems in the UK domestic sector. Energy Policy, 2007. 35: p. 4128 - 4141

37. IEA, Technology Roadmap. Solar photovoltaic energy. 2010, International Energy Agency: Paris, France.

38. Jahn, U. and W. Nasse, Operational Performance of Grid-connected PV Systems on Buildings in Germany. Progress in Photovoltaics: Research and applications, 2004. 12(6): p. 441-448.

39. Motivaction. Mentality ${ }^{\text {TM}}$-model. 2010 [cited 2010 February 7].

(C) 2011 by the authors; licensee MDPI, Basel, Switzerland. This article is an open access article distributed under the terms and conditions of the Creative Commons Attribution license (http://creativecommons.org/licenses/by/3.0/). 


\section{Appendix 1}

\begin{tabular}{|c|c|}
\hline \multicolumn{2}{|c|}{ Valuebox-model of NFO trendbox } \\
\hline Order and decency & $\begin{array}{l}\text { Women in traditional families, average income, low to secondary education, orderly, dutiful, } \\
\text { polite emphasis on social rules, security, safety, cost-conscious and thrifty, preference for } \\
\text { familiar and stable environment }\end{array}$ \\
\hline Purposeful adventure & $\begin{array}{l}\text { Young single men, high income, high education, city dweller, preference for varied and } \\
\text { comfortable life, perceptive and logical thinking, little orderly, positive future vision, } \\
\text { ambitious }\end{array}$ \\
\hline Center & Average Dutch people \\
\hline $\begin{array}{l}\text { Uncomplicated } \\
\text { beneficiary }\end{array}$ & $\begin{array}{l}\text { Young men, secondary education, need for order and discipline, ambitious and career } \\
\text { oriented, positive future vision, longing for weekend }\end{array}$ \\
\hline Sober philosophy & $\begin{array}{l}50+\text { living alone, high education, seeking for freedom and peace, inner harmony, self-respect } \\
\text { and creativity, social interest, open-minded, environmentally conscious }\end{array}$ \\
\hline Spiritual & $\begin{array}{l}\text { altruists women } 50+\text {, two-person household, secondary education, family is important, } \\
\text { equality, fairness and security, helpful and forgiving, traditional, carefully selected diet, frugal } \\
\text { and cost conscious }\end{array}$ \\
\hline \multicolumn{2}{|l|}{ Mentaltiy model [39]6 } \\
\hline Traditional citizens & $\begin{array}{l}\text { Traditional values, family is cornerstone and most important, harmony and rest, acceptance of } \\
\text { authority and rules, disciplined, risk aversive, soberly, traditional division of roles }\end{array}$ \\
\hline Comfort oriented & $\begin{array}{l}\text { Material wealth, freedom, entertainment, no responsibility, little ambition, longing for } \\
\text { appreciation, impulsive, consumption minded, outward appearance very important }\end{array}$ \\
\hline Modern citizens & $\begin{array}{l}\text { Balancing between traditional values and change, family cornerstone, social status important, } \\
\text { authority and rules, longing for appreciation, security, income and experience, technology } \\
\text { minded, regularity, traditional division of roles, risk aversive, consumption and entertainment }\end{array}$ \\
\hline New conservatives & $\begin{array}{l}\text { Traditional values, protecting social status, hierarchical, critical, interested in politics and } \\
\text { history, work is more important than private life, culture and arts, soberly, risk aversive, } \\
\text { etiquettes }\end{array}$ \\
\hline Cosmopolitans & $\begin{array}{l}\text { Success, self development, internationally oriented, interested in politics, tolerant, work is } \\
\text { central motive, ambitious, materialistic, technology minded, impulsive and adventurous, } \\
\text { status and etiquettes, arts and culture, focused on like- minded, consumption }\end{array}$ \\
\hline Upward mobiles & $\begin{array}{l}\text { Career, gaining social status, freedom from tradition and duties, change and modernization, } \\
\text { international, longing for appreciation, work and achievement, income, materialistic, } \\
\text { consumption and entertainment, technology minded, impulsive and adventurous, freedom, } \\
\text { focused on like-minded }\end{array}$ \\
\hline Post materialists & $\begin{array}{l}\text { Self development, solidarity, attention for immaterial values, interested in social life and } \\
\text { politics, reflexive, critical, solidarity, tolerant, international, balance between work and } \\
\text { private, being societal useful, principle, not consumptive and not entertainment focused, } \\
\text { sober, arts and culture }\end{array}$ \\
\hline Post modern hedonists & Freedom, independency, carpe diem, new experiences, tolerant, equal changes, not interested \\
\hline
\end{tabular}

${ }^{6}$ Description of the different groups adopted from Offermans (2010). 


\begin{tabular}{|c|c|}
\hline & $\begin{array}{l}\text { in politics or society, work subordinate to private, impulsive, adventurous, without } \\
\text { obligations, arts and popular culture, experience focused, friends more important than family }\end{array}$ \\
\hline \multicolumn{2}{|l|}{ Mosaic model } \\
\hline Free spirited & $\begin{array}{l}\text { Young, single, living alone or sharing a house with friends, well educated, multicultural, } \\
\text { involvement in the neighborhood is low, public transport, social, without obligations, aware } \\
\text { of social development and new by watching the news, public transport }\end{array}$ \\
\hline $\begin{array}{l}\text { The developed urban } \\
\text { dweller }\end{array}$ & $\begin{array}{l}\text { Quite young, begin of career, well educated, urban nomad, social, no family life, cultural, } \\
\text { reading newspapers, interested in society }\end{array}$ \\
\hline Go-getter & $\begin{array}{l}\text { Young }(<34) \text {, live alone, low educated, relatively low income, high-rise buildings, broad } \\
\text { interested, arts and culture, no car, not often on holiday }\end{array}$ \\
\hline Dynamic families & $\begin{array}{l}\text { Ambitious, self development, well educated, successful career, above average salary, live in } \\
\text { the middle of the Netherlands, new housing estate, longing for appreciation, well-filled wallet } \\
\text { is important, entertainment focused, sport/family car }\end{array}$ \\
\hline Modal citizens & $\begin{array}{l}\text { Family cornerstone, middle aged, executed jobs, below average to average salary, live often } \\
\text { in the West of the Netherlands, terraced house, used family cars, watching action movies, } \\
\text { regularly to cafeteria }\end{array}$ \\
\hline Successful families & $\begin{array}{l}\text { Family cornerstone, children of all ages, above average salary, secondary - well educated, free } \\
\text { profession or management function, live in a neighborhood near a town, child friendly } \\
\text { neighborhood, owner-occupied house, enjoying life }\end{array}$ \\
\hline Traditionalists & $\begin{array}{l}\text { From conservative to liberal and from young to old but they have one thing in common: all } \\
\text { work hard for a good life and family life, all kind of jobs, low - secondary educated, owner- } \\
\text { occupied houses, semi-detached homes, comfortable, high social cohesion, above average on } \\
\text { holidays with own caravan, support charity }\end{array}$ \\
\hline Rural family life & $\begin{array}{l}\text { Farmers and families of middle age, low-educated, above average salary, owner-occupied } \\
\text { houses, detached house, more than one car often high price, modern equipment, no designer } \\
\text { clothes }\end{array}$ \\
\hline Well-off people & $\begin{array}{l}\text { Well educated, career, well-paid professionals, far above average income, spacious villa, } \\
\text { highest social class with status and etiquettes, luxury, shopping in exclusive stores, making } \\
\text { long journeys }\end{array}$ \\
\hline Pension beneficiary & $\begin{array}{l}\text { Pensionable age, enjoy the little things in life, lower social class, low educated, apartment, } \\
\text { cultural trips, volunteer work, buy traditional products }\end{array}$ \\
\hline \multicolumn{2}{|l|}{ WIN-model $^{7}$} \\
\hline Engaged & $\begin{array}{l}\text { Harmony, stability, sociable person and prefer to do activities together with a group of other } \\
\text { people, deliberate and well considered, when making decisions you think about the impact for } \\
\text { the environment, more elderly people with a reasonably high level of education, interest in } \\
\text { arts, nature and politics, not materialistic and not interested in new innovative technologies }\end{array}$ \\
\hline Care takers & $\begin{array}{l}\text { Focused on well being of others, social person receiving energy from helping fellow human } \\
\text { beings, sober, generous for others, traditional values and traditions which provide rest and } \\
\text { security, no need for change, self effacing, community people, like to do meritorious work for } \\
\text { the (church) community, not very creative, prefer implementation over preceding }\end{array}$ \\
\hline
\end{tabular}

\footnotetext{
${ }^{7}$ Description of the different groups adopted from Offermans (2010).
} 


\begin{tabular}{|c|c|}
\hline & $\begin{array}{l}\text { development processes, both reading and television watching, regional newspapers, up to date } \\
\text { for social and political situation, fairly cheap products who are reliable, social. }\end{array}$ \\
\hline Conservatives & $\begin{array}{l}\text { Focused on your own environment, security, family is most important, do not like to attract } \\
\text { attention or seeing anybody else doing so, confirmation to rules and norms, bit impulsive, tidy } \\
\text { people, preference for unconstrained entertainment like television, disappointed with society } \\
\text { and politics, not really materialistic, but in favor of luxurious, modern stuff, confirmative. }\end{array}$ \\
\hline Hedonists & $\begin{array}{l}\text { Pleasure and enjoyment on physical and emotional level, more sportive than creative, } \\
\text { challenge, risk, adventure and excitement, not a worrier, impulsive and showing things very } \\
\text { easily (lazy), likes to go out in a group, not interested in social issues and politics, prefer } \\
\text { watching television over reading, like to spend money on going out for diner, new and novel } \\
\text { objects. }\end{array}$ \\
\hline Luxury seekers/ & $\begin{array}{l}\text { Ambitious, success, appreciation, comfort is highly valued, not somebody who keeps seated, } \\
\text { seeking challenges and does not really matter about (behavioral) rules, not very religious, ego } \\
\text { centered, not involved in other's businesses, judge quickly and talk straight from the shoulder, } \\
\text { interest in society, both television watchers and newspaper readers (mainly telegraaf), possess } \\
\text { lots of modern objects and willingness to show these to others, technological developments } \\
\text { can not go fast enough, sensitive for trends, and you will be the first one possessing a novel } \\
\text { object, achievement. }\end{array}$ \\
\hline Professionals & $\begin{array}{l}\text { Ambitious, independent, educated, self development, working hard and a quick and creative } \\
\text { thinker, free liver ("life enjoyer"), stimulating and challenging life, often double earners, high } \\
\text { income, buying luxurious, tasteful, trendy objects and sensitive to technological novelties, } \\
\text { giving money for good causes, critical but receptive for new things and point of views, } \\
\text { watches a lot of actualities and background programs on television, up to date for social } \\
\text { issues and politics, self destination. }\end{array}$ \\
\hline Broad minded & $\begin{array}{l}\text { Progressive and educated, lots of ideals who are mainly left wing, worried about social } \\
\text { problems and trying to better the world, starting with yourself, environmental consciousness, } \\
\text { keen on freedom, appreciate to make once own choices and to have a varied life with some } \\
\text { risks, self development, make great demands on oneself and others, receptive for the world } \\
\text { around, understanding, profundity, dislike prejudice, read a lot, politics and social issues } \\
\text { come from the bottom of the heart, flexible, modern, engaged. }\end{array}$ \\
\hline Balanced & $\begin{array}{l}\text { They are an average of all people. When it comes to interests, life style and so on, they are } \\
\text { exactly in the middle or other people. }\end{array}$ \\
\hline \multicolumn{2}{|c|}{ Censydiam-model of Sensovate } \\
\hline Vitality & Achieving independence \\
\hline Enjoyment & People try to maximize satisfaction of their physical and emotional needs \\
\hline Conviviality & $\begin{array}{l}\text { The need to open up socially, to really share emotions with others, to have a good time } \\
\text { together }\end{array}$ \\
\hline Belonging & The need to feel part of a group, to feel accepted and supported by their loves one \\
\hline Security & The need for comfort, tranquility, and relaxation \\
\hline Control & Control is exercised, behavior is void of emotions and feelings \\
\hline Recognitions & The need to be different, to stand out from the crowd, not drift with the current \\
\hline Power & The need to achieve success and status in life \\
\hline
\end{tabular}




\begin{tabular}{|c|c|}
\hline \multicolumn{2}{|l|}{ BSR-model } \\
\hline Yellow - Harmony & Commitment and harmony, group oriented, open minded, family \\
\hline Green - Protection & Security and safety, group-oriented, less open, smaller world, less educated \\
\hline Blue - Control & Ambition and control, performance, career, status, well-educated \\
\hline Red - Vitality & $\begin{array}{l}\text { Freedom, flexibility, independence, well-educated, active lifestyle, cultural development, } \\
\text { travelling }\end{array}$ \\
\hline
\end{tabular}

\section{Experience profiles based on BSR-model}

\begin{tabular}{|l|l|}
\hline Living together & $\begin{array}{l}\text { Prefer quiet neighborhood, plenty space in and around home, focusing on family, a preference } \\
\text { for traditional design }\end{array}$ \\
\hline Withdrawals & Looking for safe and quiet neighborhood, advanced age, strongly focused on the district \\
\hline Dynamic individualist & $\begin{array}{l}\text { Luxurious and exclusive (large and green) living, carrier-/ego-oriented, sports, performance } \\
\text { and career-oriented }\end{array}$ \\
\hline Anchored & Commitment to peace and security \\
\hline Quiet luxury & $\begin{array}{l}\text { Preference for quiet and safe living environment, focusing on social quality of the } \\
\text { neighborhood, living with like-minded }\end{array}$ \\
\hline Unattached & $\begin{array}{l}\text { urban nomad, idiosyncratic, non-conformist, well educated, not materialistic, active sports, } \\
\text { interest in culture and politics, need for privacy and anonymity }\end{array}$ \\
\hline
\end{tabular}

